УДК 373.3.091.3

DOI:

Наталія Лалак, кандидат педагогічних наук, доцент кафедри теорії та методики початкової освіти Інга Бурч, студентка ОС “магістр” Мукачівського державного університету

\title{
НАВЧАЛЬНО-ДОСЛІДНИЦЬКА ДІЯЛЬНІСТЬ МОЛОДШИХ ШКОЛЯРІВ: ТЕОРЕТИЧНИЙ АСПЕКТ
}

У статті розкрито теоретичний аспект організації навчально-дослідницької діяльності молодиих школярів. Визначено стан розробленості досліджуваної проблеми у наукових і методичних джерелах, уточнено сутність та зміст поняття “навчально-дослідницька діяльність". Авторами обгрунтовано особливості, види, етапи та визначено дидактичні функції дослідницької роботи, закиентовано увагу, щзо така діяльність формуе творчу, самостійну й ініціативну позицію молодших школярів; розвиває загальнонавчальні уміння та навички; реалізує принцип зв'язку навчання з життям.

Ключові слова: нова українська школа, молодші школярі, навчально-дослідничька діяльність, ключові компетентності, урок-дослідження.

Рис. 2. Табл. 1. Літ. 7.

Nataliya Lalak, Ph.D. (Pedagogy), Associate Professor of the Theory and Methodology of Primary Education Department

Inha Burch, Master Student Mukachevo State University

\section{EDUCATIONALAND RESEARCH ACTIVITY OFTHE JUNIOR SCHOOLCHILDREN: THE THEORETICALASPECT}

The educational and research activity in elementary school ensure the creation of the junior person's creative personality, development, education and upbringing through the active inclusion into the research of the content of any information. The issue of organizing educational and research activity of the schoolchildren is not new. In pedagogical theory and practice, its various aspects were and remain the subject of the analysis of many native and foreign scientists. The formation of the definition of "educational and research activity" was significantly influenced by T. Baibary, S. Omelchuka, O. Pometun, O. Savenkova and other modern educators and psychologists. The junior schoolchild shows a position in research differently: during observation and experiments in nature, in its understanding of the text read, the own creation of the product, the inventions of a new way of solving the problem, finding new information for the project, the analogy between distant phenomena and features. It has been found out by the authors, that the organization of research activity in elementary school should take into account the age-old ability of children and be implemented in accordance with certain stages. A modern teacher of elementary school should consider and plan during which subject it is appropriate and possible to conduct a research; what tasks can be put for the schoolchildren during the implementation of the work; how to coordinate the actions of schoolchildren at the stage of preparation of the research and during the research work.

In the context of the definition of didactic functions of educational and research activity of junior schoolchildren, valuable for our study are the views of I. Pidlasoho, who defined the functions of educational and research activity: motivational, informational, control-correcting. Within the modern personality-oriented model of education, the educational institutions should take into account the abilities, needs and interests of junior schoolchildren and organize the educational process with the elements of search and research work.

Keywords: new Ukrainian school, the junior schoolchildren, an educational and research activity, key competence, a lesson-research.

П остановка проблеми. У Концепції Нової української школи зазначено, що сучасним школярам недостатньо дати знання, важливо навчити їх користуватися ними. Знання та уміння, взаємопов'язані 3 ціннісними орієнтирами учня, формують його життєві компетентності, які потрібні для успішної самореалізації у житті, навчанні та праці.

Для формування ключових і предметних компетентностей у процесі шкільної освіти необхідно використовувати педагогічні технології навчання, які створюють умови для набуття досвіду діяльності. I провідне місце тут належить навчально-дослідницькій діяльності, адже вона: формує творчу, самостійну й ініціативну позицію учнів; розвиває загальнонавчальні уміння та навички; реалізує принцип зв'язку навчання 3 життям. Навчально-дослідницька діяльність забезпечує створення творчої особистості, їі розвиток, навчання і виховання за допомогою 


\section{НАВЧАЛЬНО-ДОСЛІДНИЦЬКА ДІЯЛЬНІСТЬ МОЛОДШИХ ШКОЛЯРІВ: ТЕОРЕТИЧНИЙ АСПЕКТ}

активного включення в дослідження змісту будьякої інформації.

Аналіз основних досліджень і публікацій. Проблема організації навчально-дослідницької діяльності учнів не є новою. В педагогічній теорії та практиці різні їі аспекти були й залишаються предметом аналізу багатьох вітчизняних та зарубіжних учених. Наукове осмислення поняття “навчально-дослідницька діяльність” грунтується на ідеях Сократа, Конфуція, Ж.-Ж. Руссо, Дж. Локка,Я. Коменського, Ф. Дістервега, О. Духновича, К. Ушинського, В. Сухомлинського, С. Русової, Б. Райкова, та ін., які в певні історичні періоди розвитку людства наголошували на необхідності організації навчання, спрямованого на відкриття суб'єктивно нових знань і способів діяльності. Основою для зародження смислового поля поняття "навчально-дослідницька діяльність" слугують праці, у яких розглянуто навчальну діяльність та ii структуру (П. Гальперин, В. Давидов, Н. Тализіна,), особливості організації такої діяльності в початковій школі (Т. Байбара, Н. Бібік, М. Вашуленко, Я. Кодлюк, О. Онопрієнко, О. Савченко та ін.). На формування дефініції “навчально-дослідницька діяльність” суттєво вплинули роботи Т. Байбари, С. Омельчука, О. Пометун, О. Савенкова та інших педагогів і психологів.

Мета статті - провести ретроспективний аналіз досліджуваної проблеми і теоретично обгрунтувати особливості організації навчальнодослідницької діяльності молодших школярів.

Виклад основного матеріалу. Оскільки, сучасному суспільству потрібен не виконавець, а творець, людина, що здатна жити в інформаційному просторі і своєю діяльністю створювати цей простір, то навчальнодослідницька діяльність школярів має виняткове значення на рівні освітньої практики. Пошукова активність $€$ своєрідним внутрішнім генератором, який робить дитину творчою.

Поділяємо думку О. Савченко, яка зазначає, що розвивальний вплив навчального середовища у початковій школі стає більш помітним, за умови, якщо дитина вступає 3 ним в активний пізнавальний контакт та набуває продуктивної взаємодії. Дослідницька діяльність $є$ широкою за змістом і різнорівневою за типом пізнання, тобто здійснюється практично й теоретично [6]. Молодший школяр проявляє дослідницьку позицію по-різному: під час спостереження й дослідів у природі, в своєму розумінні прочитаного тексту, уявному діалозі з його автором, власноручному створенні виробу, придумуванні нового способу розв'язування задачі, знаходженні нової інформації для проекту, аналогії між віддаленими явищами, ознаками тощо [3].

Як показує практика, дослідницька діяльність пов'язана з виконанням творчого, дослідницького завдання із заздалегідь невідомим рішенням. Це така діяльність, що здійснюється 3 навчальною метою і передбачає дотримання певних етапів, які $\epsilon$ характерними для наукового дослідження: визначення проблеми; ознайомлення 3 літературними джерелами та їх опрацювання; формулювання гіпотези дослідження; власне проведення дослідження, аналіз його результатів i остаточне узагальнення; формулювання висновків; конкретна суспільно корисна робота учнів за результатами здійсненого дослідження [4].

Логіка нашого дослідження вимагає з'ясувати сутність поняття “навчально-дослідницька діяльність”. У словнику педагогічних термінів ця дефініція трактується як процес вирішення школярами наукових та особистісних проблем 3 метою побудови суб'єктивно нового знання. Порізному розглядають це поняття науковці. Окремі трактування подано в таблиці 1 .

До 70-х років XX століття науковці та педагогипрактики використовували поняття “навчальнодослідницька діяльність” і “дослідницька діяльність” як синоніми $[4,20]$. Період розрізнення їх співвідноситься 3 початком процесу розробки стратегій реформування початкової ланки освіти на початку 80 -х років XX століття. Смислове поле базового поняття “дослідницька діяльність учнів" можна схарактеризувати такими тезами:

- така діяльність учнів $є$ видом пізнавальної діяльності;

- здійснюється учнями поетапно $з$ дотриманням певної послідовності дій;

- являє собою процес наукового пізнання, доступний учням у процесі відтворення, сприймання й розуміння;

- вона набуває форми навчального дослідження.

У науковій літературі знайшли відображення результати порівняння навчального дослідження 3 науковим. До прикладу, С. Омельчук, розглядає такі спільні ознаки навчального й наукового досліджень: 1) етапність; 2) теоретичний та емпіричний характер; 3) можливість індивідуального й колективного проведення дослідження $[4,53]$.

У контексті визначення дидактичних функцій навчально-дослідницької діяльності молодших школярів цінними для нашого дослідження $\epsilon$ погляди I. Підласого [5]. Науковець визначає функції навчально-дослідницької діяльності. Зокрема, це: 


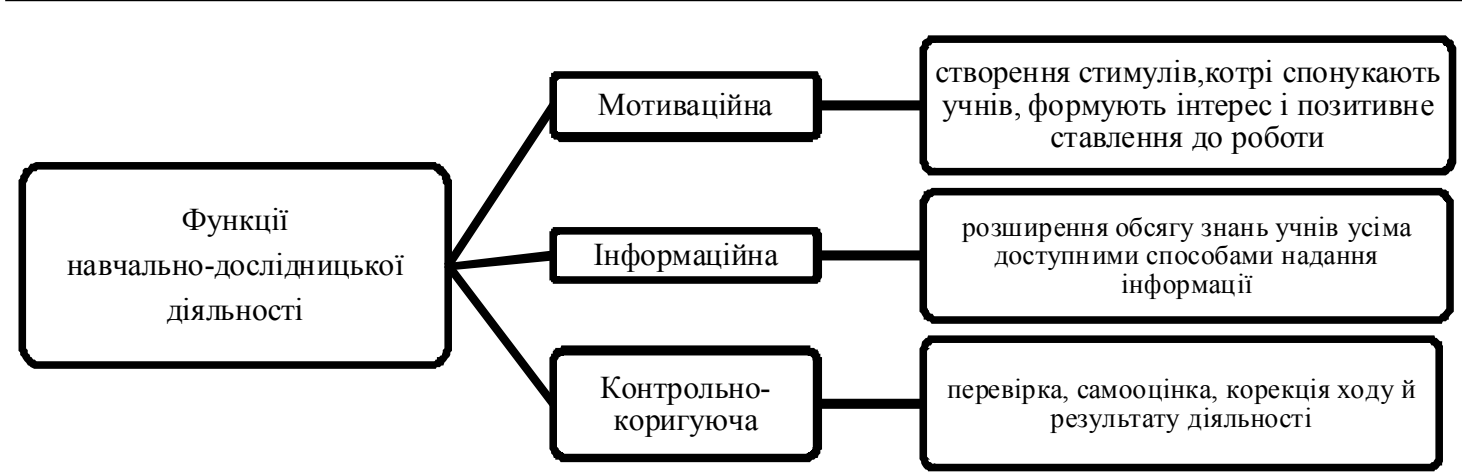

Рис. 1. Функції навчально-дослідницької діяльності

Таблиця 1.

Сутність поняття "навчально-дослідницька діяльність"

\begin{tabular}{|c|c|}
\hline Л. Голодюк & $\begin{array}{l}\text { спрямована вчителем діяльність учня, у результаті якої в останнього формуються } \\
\text { узагальнені способи дії розв’язання індивідуально або суспільно значущих задач }\end{array}$ \\
\hline П. Підкасистий & $\begin{array}{l}\text { вища форма самостійного навчального пізнання, оскільки вона набуває форми } \\
\text { наукового передбачення, де учень ставить власну мету й шукає способи } \\
\text { досягнення результату. }\end{array}$ \\
\hline $\begin{array}{l}\text { Н. Полтавцева та } \\
\text { Н. Філюшина }\end{array}$ & $\begin{array}{l}\text { діяльність, яка спрямована на створення якісно нових важливих для розвитку } \\
\text { особистості цінностей, у ході діяльності передбачено самостійне оволодіння } \\
\text { новими знаннями та способами дій. }\end{array}$ \\
\hline Н. Семенова & $\begin{array}{l}\text { спеціально організована пізнавальна творча діяльність учнів, що за своєю } \\
\text { структурою відповідає науковій діяльності, характеризується активністю, } \\
\text { предметністю та свідомістю; результатом діяльності є формування пізнавальних } \\
\text { мотивів, дослідницьких умінь, суб’єктивно нових для учнів знань та (або) } \\
\text { способів діяльності }\end{array}$ \\
\hline І. Клєщова & $\begin{array}{l}\text { діяльність, характеристиками якої є внутрішня мотивація; спеціальні структурні } \\
\text { компоненти; високий ступінь самостійності учня під час здійснення навчально- } \\
\text { дослідницької діяльності в цілому; отримання суб'єктивно нового результату, } \\
\text { який збагачує систему знань учня. }\end{array}$ \\
\hline О. Обухова & $\begin{array}{l}\text { творчий процес спільної діяльності двох суб’єктів (учителя й учня) } 3 \text { пошуку } \\
\text { невідомого, у ході якого здійснюється трансляція між ними культурних } \\
\text { цінностей, результатом котрої є формування світогляду. }\end{array}$ \\
\hline Г. Лиходсєва & $\begin{array}{l}\text { діяльність учнів, що організовується педагогом з використанням різних форм і } \\
\text { дидактичних прийомів; за здійснення якої домінує самостійне свідоме } \\
\text { використання методів наукового пізнання; у результаті якої учні активно } \\
\text { оволодівають знаннями, розвивають дослідницькі вміння та здібності. }\end{array}$ \\
\hline С. Антоновою & $\begin{array}{l}\text { процес набуття дослідницьких і супутніх дослідженню умінь у процесі взаємодії } \\
\text { учнів і педагога, яка спрямована на виявлення сутності тієї чи іншої проблеми, } \\
\text { актуальної для суб'єктів діяльності. }\end{array}$ \\
\hline Н. Головізніна & $\begin{array}{l}\text { продуктивна навчальна робота проблемно-пошукової спрямованості, основу якої } \\
\text { складає серйозна мисленнєва діяльність, виконання якої потребує спеціальних } \\
\text { умінь для самостійного виконання навчальної праці }\end{array}$ \\
\hline
\end{tabular}

Варто акцентувати увагу на особливостях організації вчителем початкової школи навчальнодослідницької діяльності школярів. Зокрема, це:

- використання різних форм, дидактичних прийомів, засобів опосередкованого й перспективного керівництва, серед яких домінує самостійне і свідоме використання методів наукового пізнання та творча спрямованість змісту розумових операцій;

- педагогічне управління процесом формування навчально-дослідницьких умінь;

- спільний творчий процес 3 пошуку невідомого, у ході якого здійснюється трансляція культурних цінностей;

- пошук, пояснення й доведення закономірних зв'язків та відношень фактів, явищ, процесів, які експериментально спостерігаються або теоретично аналізуються; самостійне застосування учнями прийомів наукових методів пізнання; виявлення сутності тієї чи іншої проблеми, актуальної для суб'єктів діяльності; створення інтелектуального продукту, пов'язаного зі встановленням істини в результаті процесу дослідження; 


\section{НАВЧАЛЬНО-ДОСЛІДНИЦЬКА ДІЯЛЬНІСТЬ МОЛОДШИХ ШКОЛЯРІВ: ТЕОРЕТИЧНИЙ АСПЕКТ}

- передбачення результату, формулювання цілей та гіпотези, пошук самостійних шляхів вирішення поставленої мети та обгрунтовування правильності рішень;

- мотивація до виявлення самостійності під час здійснення навчально-дослідницької діяльності в цілому або на окремих іiі етапах.

На нашу думку навчально-дослідницька діяльність буде ефективною, якщо відповідатиме низці вимог: поєднання 3 різними видами пізнавальної діяльності; усвідомленість учнем сутності проблеми; цілеспрямованість пошукової творчої і продуктивної діяльності; самостійність пошуку учнями відповідей; реалізація потенційних здібностей учнів; організація досліджень 3 урахуванням можливості задоволення потреб учнів під час спілкування 3 однокласниками, батьками, вчителями; набуття навичок самостійної роботи та співпраці у колективі; забезпечення співпраці “учень вчитель” на основі принципу рівноправності, партнерства.

Педагоги-практики розрізняють такі види навчально-дослідницької діяльності:

- за кількістю учасників - індивідуальна, групова, колективна;

- за місцем проведення - урочна і позаурочна;

- за часом - короткотривала та довготривала;

- за темою - освітня і соціальна $[1,17]$.

Аналіз сучасної теорії і практики організації навчально-дослідницької діяльності засвідчив, що взаємодія вчителя з учнями реалізується як рефлексивна суб'єкт-суб' єктна. На відміну від механічної взаємодії (“запитання-відповідь”), ця взаємодія спрямовується на обмін думками. Налагодженню рефлексивної суб' Єкт-суб' єктної взаємодії сприяють дії вчителя, які спрямовано на прийняття учнями навчальної мети, стимулювання їх до висловлювання власних думок, прийняття різних ставлень і міркувань стосовно визначеної проблеми. Взаємодія вчителя з учнями здійснюється здоцільним використанням різних прийомів, у тому числі й прийому створення ситуації співроздумів (постановка риторичних, проблемних, відкритих запитань, створення проблемної ситуації в процесі зіставлення різних думок, фактів, подій, способів дій, розв'язків тощо) та прийому створення ситуації співпереживання [3].

У літературі з проблеми дослідження $[1 ; 2 ; 3$; 4; 7] знаходимо, що одним із видів організації навчальної діяльності молодших школярів $\epsilon$ навчальне дослідження. За А. Щукіним, таким дослідженням передбачено організацію пошукової творчої діяльності учнів шляхом постановки нових проблем і проблемних завдань. С. Омельчук розглядає навчальне дослідження як складник технології дослідницького навчання, оскільки “під час навчального дослідження встановлюється пізнавальна і практична значущість виучуваного матеріалу, активізується мисленнєва діяльність учнів, посилюється ступінь їхньої пізнавальної самостійності й активності" [4]. У працях вітчизняних та зарубіжних науковців зазначено, що організовуючи навчально-дослідницьку діяльність, учитель початкової школи має передбачати використання міжпредметних зв'язків, реалізацію сучасних технологій та методик цілеспрямованого формування дослідницьких умінь на основі комплексного підходу до навчально-виховного процесу.

На нашу думку, організація дослідницької діяльності в початковій школі має враховувати вікові можливості дітей та реалізовуватися 3 дотриманням певних етапів (рис. 2):

Етап виявлення проблеми (протиріччя) та усвідомлення iї (його)

змісту

Етап застосування відомих учням знань і способів діяльності для вирішення проблеми (подолання протиріччя)

Етап формулювання припущення або висунення гіпотези щодо способу чи результату розв'язання проблеми (подолання протиріччя)

Етап послідовного виконання дій з виявлення істинності чи хибності висунутого припущення

Етап формулювання висновків на основі отриманих даних

Рис. 2 Етапи організації дослідницької діяльності 
Зокрема, на перших етапах учень актуалізує наявний у нього досвід і обмінюється власними думками 3 іншими учасниками діяльності або набуває досвід безпосередньо в процесі здійснення діяльності за допомогою спеціально організованої взаємодії. Суть діяльності полягає в пошуках нового, в життєвому досвіді, уявленнях, опорних знаннях, практиці діяльності безпосередньо на уроці, 3 чим варто попрацювати в рамках навчальної теми. На наступному етапі педагогом створюються умови для критичного осмислення інформації, рефлексії учнями набутого досвіду, обговорення спостережень, які супроводжували процес його набуття [7]. На четвертому етапі навчання здійснюється осмислення інформації, перехід від реальних ситуацій особистої практики до узагальнених висновків. Ефективність роботи учнів на цьому етапі підвищується завдяки спільній рефлексії, загальним міркуванням, обміну ідеями, смислами результати взаємодії відображаються учнями в сформульованих висновках. На основі колективного мислення виникає унікальне знання, цінність якого полягає не в інформативності його змісту, а в творчому характері його утворення. На заключному етапі особливого значення набуває можливість перевірки учнями змісту сформульованих висновків. Така поетапність дослідницької роботи молодших школярів реалізується у ході проведення уроку-дослідження. Сучасному вчителю початкової школи слід обміркувати та спланувати під час вивчення якої навчальної теми доречне і можливе проведення дослідження; які завдання можугь бути поставлені перед учнями в ході виконання роботи; як скоординувати дії учнів на етапі підготовки дослідження та протягом проведення дослідницької роботи $[2,28]$.

Висновки та перспективи подальших досліджень. Нова українська школа працює сьогодні на засадах особистісно-орієнтованої моделі освіти. У рамках цієї моделі навчальні заклади повинні максимально враховувати здібності, потреби та інтереси дитини, на практиці реалізуючи принцип дитиноцентризму. Аналіз практичної діяльності сучасних ЗНЗ дає підстави стверджувати, що навчальний процес у них характеризується елементами пошукової та дослідницької роботи, оскільки це сприяє ефективному вивченню програмового матеріалу та урізноманітненню освітнього процесу. Метою навчально-дослідницької діяльності молодших школярів має бути не тільки кінцевий результат, а й сам процес пошуку, під час якого розвиваються дослідницькі здібності учнів, відбувається розширення їх світогляду, зміна не лише мотивації до навчання, а й заміна об'єктної ролі на суб'єктну.

Перспективи подальших досліджень вбачаємо у розкритті практичного аспекту організації навчально-дослідницької діяльності молодших школярів, зокрема на уроках природознавства, математики та літературного читання.

\section{ЛITЕРАТУРА}

1. Гільберг Т. Навчально-дослідницька діяльність на уроках природознавства / Т. Гільберг, Т. Сак // Учитель початкової школи, 2014. - №7-8. - С. 1517.

2. Кисель Л. Дослідницька діяльність на уроках літературного читання / Л. Кисель // Учитель початкової школи, 2017. - №1 - С. 28 - 31.

3. Коломієць М. Навчально-дослідницька діяльність дітей молодшого шкільного віку / М. Коломієць// Завучу. Усе для роботи. - 2015. - № 9-10. - C.25-29.

4. Мієр Т. І. Організація навчально-дослідницької діяльності молодших школярів у взаємодії з собою та 3 іншими: монографія / Тетяна Мієр. - Кіровоград: ФО-П Александрова М. В., - 2016. - 424 с.

5. Підласий І. П. Педагогіка: 100 питань -100 відповідей: навчальний посібник для студентів вищих навчальних закладів / І. П. Підласий. - М.: Видавництво ВЛАДОС - ПРЕС, 2004. - 267 с.

6. Савченко О. Я. Навчальне середовище як чинник стимулювання дослідницької діяльності молодших школярів / О. Я. Савченко // Наукові записки Малої академії наук України. - 2012. - №.1. - С. 41 - 49.

7. Скворцова С. Урок-дослідження з математики у початковій школі / С. Скворцова, О. Онопрієнко // Початкова школа. - 2015. - № 12. - С. 13-17.

\section{REFERENCES}

1. Hilberh, T. (2014). Navchalno-doslidnytska diialnist na urokakh pryrodoznavstva [Educational and research activity at the lessons of natural science]. Elementary school teacher, vol.7-8, pp. 15-17. [in Ukrainian].

2. Kyse1, L. (2017). Doslidnytska diialnist na urokakh literaturnoho chytannia [Research activity at literary reading lessons]. Elementary school teacher, vol.1, pp. 28 - 31. [in Ukrainian].

3. Kolomiiets, M. (2015). Navchalno-doslidnytska diialnist ditei molodshoho shkilnoho viku [Educational and research activity of children of elementary school age]. Zavuchu. Use dlia roboty, vol.9-10, pp.25-29. [in Ukrainian].

4. Miier, T. I. (2016). Orhanizatsiia navchalnodoslidnytskoi diialnosti molodshykh shkoliariv $u$ vzaiemodii z soboiu ta $z$ inshymy [Organization of educational and research activity of junior pupils in interaction with themselves and with others]. Kirovohrad: FO-P Aleksandrova M. V. Publ., 424 p. [in Ukrainian].

5. Pidlasyi, I. P. (2004). Pedahohika: 100 pytan100 vidpovidei [Pedagogy: 100 questions - 100 
answers]. Moscov: Vydavnytstvo VLADOS - PRES Publ., 267 p. [in Ukrainian].

6. Savchenko, O. Ya. (2012). Navchalne seredovyshche yak chynnyk stymuliuvannia doslidnytskoi diialnosti molodshykh shkoliariv [Educational surrounding as a factor in stimulating the research activities of junior pupils]. Scientific notes of the Junior Academy of Sciences of Ukraine, vol. 1, pp. 41 - 49. [in Ukrainian].

7. Skvortsova, S. \& Onopriienko, O. (2015). Urokdoslidzhennia z matematyky u pochatkovii shkoli [Research lesson on math in elementary school] Elementary School, vol. 12, pp. 13-17. [in Ukrainian].

Стаття надійшла до редакції 09.03.2018

УДК 378.016:376

DOI:

Юрій Долинний, кандидат педагогічних наук, дочент, докторант кафедри педагогіки і методики технологічної освіти Глухівського національного педагогічного університету імені О. Довженка

\section{СТАТИСТИЧНА ОБРОБКА ПОКАЗНИКІВ МОТИВАЦЙНОГО ТА КОГНІТИВНОГО КРИТЕРІЮ ГОТОВНОСТІ МАЙБУТНІХ БАКАЛАВРІВ З ФІЗИЧНОГО ВИХОВАННЯ І СПОРТУ ДО РЕАБІЛІТАЦІЙНОЇ РОБОТИ З ДІТЬМИ 3 ОБМЕЖЕНИМИ ФІЗИЧНИМИ МОЖЛИВОСТЯМИ}

У статті розглянуто показники мотиваиійного та когнітивного критерію готовності майбутніх бакалаврів з фізичного виховання і спорту до реабілітаиійної роботи з дітьми з обмеженими фізичними моэливостями.

При виріменні завдань дослідження реалізачії практичної складової системи професійної підготовки фахівиів з фізичного виховання $і$ спорту до реабілітаційної роботи з дітьми з обмеэсеними фізичними можливостями була застосована математична статистика та аналізувались наступні показники статистичноі обробки: середнс арифметичне значення величини ( $\overline{\mathrm{X}})$; помилка обчислення середньої арифметичної величини $(s) ;$ середнє квадратичне відхилення, якехарактеризує мінливість ознаки $(\sigma)$ вірогідність різнииі середніх величин (t). Оиінка вірогідності різниці статистичних показників (t) проводилась за критерієм Стьюдента. Для перевірки достовірності покращееня результатів контрольних тестів значення $F$ розрахункового порівнювались 3

критичними $F_{\alpha, \gamma 1, \gamma 2}$ із таблиці теоретичного розподілення Фімера для $\alpha=0,05$.

Ключові слова: дослідження, експеримент, математична статистика, арифметичне значення, фахівиі, фізичне виховання, реабілітація, професійна підготовка.

Рис. 4. Табл. 4. Літ. 10.

Yuriy Dolynnyi, Ph.D. (Pedagogy), Associate Professor, Doctoral Student of the Pedagogics and Method of Technological Science Department Hlukhiv Oleksander Dovzhenko National Pedagogical University

\section{STATISTICALTREATMENT OFINDEXES OF MOTIVATIONALANDCOGNITIVE CRITERION OFREADINESS OF FUTURE BACHELORSOFPHYSICALEDUCATIONAND SPORTTO REHABILITATIONWORKWITHCHILDRENWITHLIMITPHYSICALPOSSIBILITIES}

The article presents the indexes of motivational and cognitive criterion of readiness of future bachelors of physical education and sport to rehabilitation work with children with limit physical possibilities.

At the decision of tasks of research to realization of the practical component system of professional preparation of specialists on physical education and sport to rehabilitation work with children with limit physical possibilities were applied the mathematical statistics and such parameters were analyzed: mean arithmetic value of size $(\overline{\mathrm{X}})$ error of calculation of arithmetic average (s); standard deviation that characterizes the changeability of sign $(\sigma)$ authenticity of difference of averages $(t)$. The estimation of authenticity of difference of statistical indexes $(t)$ was conducted on the criterion of students. For verification of authenticity of improvement of results of control tests of value of $F$ calculation compared to critical from a theoretical allocation of Fisher map for $=0,05$.

Keywords: a research, an experiment, mathematical statistics, arithmetic value, the specialists, physical education, rehabilitation, professional preparation.

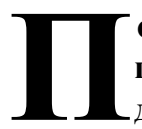

остановка науково-практичної проблеми. Процес становлення нашої держави, демократичний розвиток суспільства, соціальна політика України вимагає переходу до нового типу гуманістичноінноваційної фізкультурної освіти, яка
(C)

Ю. Долинний, 2018 